\title{
SOME ECONOMIC ISSUES IN ROBINSON-PATMAN LAND
}

\author{
JoHN S. MCGEE*
}

\section{INTRODUCTION}

We are in the thirtieth year of something called the Robinson-Patman Act. ${ }^{1}$ In the study of obscure poetry and lost cities, as with Robinson-Patman, there have been many efforts to discover the intentions of authors and builders both for the sport of quest and to learn what and where things are and what they mean. Archaeology, geology, and case-watching are not useless. For holy men and technicians versed in them can earn their fees. It is worth something to neutralize curses for drilling into sacred tombs. It will pay to avoid (or prepare for) the pains of blundering into minefields and cutting into geyser sources, even if no high social purpose is served by their being there in the first place. The task of the antitrust bar is harder, and the fees higher, in some part, I suppose, because the law may move.

There is some evidence that Robinson-Patman standards may now be shifting, even for eternals like brokerage, costs, and competitive "injury." Nevertheless, in this paper I have wholly avoided the temptation to review cases and to point out shocking or pleasing ways in which the law appears recently to have changed, or failed to change. I have done so for several reasons. Given the instability of legal trajectories and the character of case reports, the law reviews and other professional sources have handled the case-to-case accumulation about as well as can be; and voluminous treatises have added further to our sense of history and prospect. ${ }^{2}$ Although recent changes can raise false hopes and obscure larger and more abiding issues, times of change are good ones for rethinking old and new goals. For reason may channel movement. Further, to be somewhat less hopeful, the reports may serve well enough as symbols for long-run legal classifications; but I am leery about using them as empirical evidence for policy evaluation. Finally, as an economist I think a different job needs to be attempted with Robinson-Patman. Although for a long time good and bad economics has been filtering into antitrust, in recent years scholars have begun systematically to take the law apart, using the machinery of economic theory together with empirical observation. The process has now gone far in academic circles; and I think we are on the threshold of a much more open intellectual debate about antitrust policy. ${ }^{3}$

-A.B. 1947, University of Texas; Ph.D. r952, Vanderbilt University. Professor of Economics, Duke University.

${ }_{4} 49$ Stat. $\times 526$ (1936), $1_{5}$ U.S.C. $\$ \mathrm{r}_{3}-\mathrm{r} 3 \mathrm{~b}, 2 \times 2$ (1964).

"See, e.g., Corwin D. Edwards, The Price Discrimination Law (1959); Frederick C. Rowe, Price Discrimination Under the Robinson-Patman Act (r962) and Supplement (ig64).

${ }^{3}$ What is relatively novel is not contention but that opposing academics, many of whom share the same economic objectives, are digging to the roots of rival theories and visions of reality. What is going on is not business apology but academic radicalism in the best sense. 
Aaron Director of the University of Chicago has been a powerful participant and influence in completely re-analyzing the law, theory, and facts of monopolizing practices, for example. The work of Morris Adelman, particularly with respect to Robinson-Patman, has become classic.5 Both have shown the merits, and surprises, of going to transcripts of record rather than to the reports. A recent spirited exchange in a leading law review is more evidence. ${ }^{0}$ Old assumptions and assertions are being ventilated. The antitrust field will never be the same again.

It would be presumptuous both to announce a new wave and to claim to be riding on it. But what I will try here is to comment on a few Robinson-Patman problems in a spirit that I hope will not only be consistent with that of the new debate but will contribute in small ways to it. I do not proceed section by section to analyze the meaning or effect of the statute; and I ignore completely sections 2(c) through $2(f)$. This essay may not help anybody win a case. I hope it will persuade or shock some practitioners, academics, and jurists into revisiting their logic, transcripts, and the real world.

\section{Priorities in ANTITRUst}

If there is anything that economics can teach us it is that we cannot do as much of everything as we would like at the same time. Knowingly or not, we all proceed under some system of priorities. It may be random, rational, or perverse. Antitrust is also subject to principles of scarce resources. Whether antitrust is or should be motivated by purely economic considerations is perhaps debatable. Nevertheless, as an economist I will concentrate on economic values, leaving others aside. This is more convenient and useful than purely narrow-minded, for it would be helpful to everyone to know what it costs to pursue noneconomic goals. In addition, the discussion will prove useful for a later section. To establish priorities requires standards of importance.

Economic priorities are based on alternative costs and benefits. Classical economics furnishes some guidelines. A key concept is full competitive equilibrium, one important conceptual benchmark for judging economic performance. In full equilibrium no firm would have any incentive to alter its output rate or to leave the industry of which it is a part. The firm's total proceeds would precisely equal its total costs, including competitive returns on owners' capital and sweat. No one outside the industry could improve his position by entering it. The industry would be of equilibrium size. For each firm, marginal cost-the change in total cost accompany-

\footnotetext{
'See his classic article with Edward H. Levi, Law and the Future: Trade Regulation, 5I Nw. U.L. REv. 28 I (1956).

5 For a bibliography through 1961, see Pacrer, The State of Research in Antitrust Law 154-55 n.I6 (1963).

Bork \& Bowman versus Blake \& Jones, The Goals of Antitrust: A Dialogue on Policy, 65 CoLum. L. REv. 363 (1965).
} 
ing a unit change in output-would equal price. In a competitive world, costs would reflect returns to resources in alternative uses. Hence, marginal costs would approximate the worth of what is being given up to produce the good in question.

Similarly, in equilibrium, consumers would have no incentive to alter their consumption patterns. Given tastes, income distribution, and the prices of all goods and services, the traditional theory argues that this equilibrium pattern maximizes consumer satisfaction. Consumers' satisfaction is the god; the competitive process and market mechanism-together with firms and factors of production-are judged by how well they serve it.

Of course, even competitive equilibrium need not always be "full" in that sense. Though prices everywhere equaled each existing firm's marginal cost, in the short run revenues could exceed or fall short of total costs. Profits indicate areas in which goods are "worth" more than they cost to produce, and new firms will spring up until equilibrium is achieved. Losses shrink an industry.

Monopoly is something else again. If it does anything relevant, monopoly raises price above marginal cost, i.e., makes price higher than the worth of resources necessary to do the job. As a consequence, consumers buy less of a monopolized good, and more of other goods, than would otherwise be the case. According to traditional theory, consumer satisfaction is thereby reduced. It is this allocative and real income effect-too little production of monopolized goods and too much of competitive goods-that is really at issue, and not whether a monopolist is rich. In theory, at least, it would be possible to measure the loss in consumer welfareroughly one-half of the product of quantity reduction and price increase-because of monopoly, and there have been some attempts to do so.?

The purely economic rationale for antitrust or monopoly regulation must be that it increases consumer welfare both by more than it costs and by more than the same volume of resources could accomplish in other ways. ${ }^{8}$ Nevertheless, I will uncritically accept the total antitrust budget as given. However its amount is determined, the antitrust budget should be allocated to maximize the satisfaction of

\footnotetext{
${ }^{7}$ See Harberger, Monopoly and Resource Allocation, 44 AM. Econ. Rev. 77 (1954), and threc articles by Schwartzman: The Effect of Monopoly on Price, 67 J. Pol. Econ. 352 (1959); The Burden of Monopoly, 68 id. 627 (1960); The Effect of Monopoly: A Correction, 69 id. 494 (1961). But see Stigler, The Statistics of Monopoly and Merger, 64 J. PoL. Econ. 33 (1956); Lancaster \& Lipsey, The General Theory of Second Best, 24 Rev. Econ. Studies iI (1957); E. J. Mishan, Welfare Economics: Five INTROductory Essays, esp. xii-xv, 24-27, 28-30, 79-80, 155-83 (1964).

${ }^{8}$ Costs of fear, avoidance, and litigation are additional taxes on business subject to the law. Their full allocation and income distribution effects are, in practice, somevhat obscure.

One neglected implication of monopoly theory should be noted at this point. Traditional analysis has it that the gain to monopolists is less than the loss to consumers-i.e., that there is a "dead-weight" loss from monopoly. For a simple introduction to the point, see PaUl A. Samuelson, Economics, AN INTRODUCTORY ANALYsIs 496-97 (6th ed. I964). It therefore appears that consumers could buy out monopolies (for prices that would satisfy their owners) and still be better off. On this simplified level, however, there could still be a rationale for antitrust. In the first place, it may be prohibitively expensive or administratively impossible to form the necessary syndicate of large numbers of consumers. Second, it is possible that government can break (or avoid) the monopoly for less than it would take to buy out the monopoly.
} 
consumers and not that of agency staffs, businessmen, or other special interests. If it is legitimate to ignore possible net values of antitrust as entertainment, the goal is to attack (or avoid) the most important monopolies or monopolizing practices within the reach of law.

Subtle questions arise with respect to "importance." If a potential antitrust case could yield general, unambiguous, and self-diffusing rules, its proper priority position would have little to do with the importance of the industry or monopoly with which it specifically deals. Agencies might properly try to generate as much (and hopefully as valid) principle as possible-even if developed from trivial industries-for

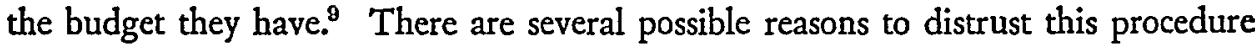
in the real world. Case-by-case economics and law often lack explicit and coherent theoretic underpinning. As a consequence, the whole procedure has an ad hoc flavor, which is often emphasized by emptily formalistic distinctions between fact situations that often differ in economically irrelevant ways. However desirable or inevitable this may be in law, it defers or bars rules of general application. Even if this were not so, whatever general rules do emerge are not self-diffusing. Out of millions of firms and billions of transactions very few are chosen for antitrust action. Even if it is expensive to be chosen, odds are long. It is not surprising that many businessmen claim they pay absolutely no attention to the Robinson-Patman Act In any case, it is not proved that statutes like Robinson-Patman have large effects on business conduct generally. ${ }^{10}$

Some of the foregoing argument sounds as though antitrust enforcement is random. Apparently it is not, which may be a mixed blessing. There are several reasons to suppose nonrandomness in actual antitrust enforcement. For example, it is conceivable that the criteria by which agency performance is judged and differences in emphasis in the statutes may encourage the selection of many relatively sure, but economically trivial, cases. The historic preponderance of section 2(c) cases, for example, and the apparent increase in other per se types of RobinsonPatman proceedings may not be fortuitous.

Of course, there is nothing inherently evil in nonrandomness; but bias should make sense. ${ }^{11}$ For, even if all that traditional static theory says is taken whole, all existing or threatened monopolies are not equally important. And, if legal rules are both ambiguous and applied case-by-case, it makes sense to emphasize the probable direct consequences of each case. From the standpoint of economic

\footnotetext{
${ }^{\circ}$ If results of policy are perverse, priorities might profitably be reversed. Application of perverse rules might then be made as expensive as possible and confined to as few and as trivial areas as possible.

${ }^{10}$ Nor, to digress, is it clear to me that present procedures against mislabeling, inflammable sweaters, and so forth are more effective (or efficient) than simply publicizing quality findings á la Constumer Reports. Similarly, it is conceivable that substantial rewards to informers-geared to valueadded or, even, sales-might prove more worthwhile in combating cartels than less direct approaches.

${ }^{11}$ The drift of this argument is especially likely to infuriate those who think in terms of common criminal offenses. Is one murder (and murder-victim) more important than another? So far as economics is concerned, the answer is, clearly, "yes."
} 
efficiency, what should be opposed are those monopolies that would or actually do most reduce output and raise price for the longest time. For this appraisal the absolute quantities are highly relevant. A small increase in price on a very large volume has the same economic importance as a large increase in price on a small volume. Each individual case of small price effects on small volumes is simply trivial unless such effects last correspondingly longer. Rational priorities for the antimonopoly laws seem at least to require estimates of $(I)$ the industry and/or monopolizing firm's $(a)$ costs and $(b)$ demand elasticities over a range of prices and (2) the probable duration of the existing or prospective monopoly under consideration.

These look like modest requirements; ${ }^{12}$ but perhaps we can be content, or at least better off than we now are, with even less. The Robinson-Patman Act and the Clayton Act ${ }^{13}$ deal importantly with incipient monopoly. A marked change in the pattern of litigation might occur even if the Federal Trade Commission ranked potential cases by simply asking (and honestly answering) the following questions with respect to each: (I) if the most pessimistic view of this industry's development is correct, approximately how much will consumers suffer? (2) What is the most probable consumer loss? (3) How long is it reasonable to suppose that either resulting distortion would persist? Perhaps price discrimination cases would still be brought against firms making rubber stamps, flax rugs, garments, or numbering machines and against atomistic fish and food packers, brokers, and other market intermediaries; but one could hope not. ${ }^{14}$

Survival characteristics of antitrust administrators and lawyers, as well as those of college professors, are substantially influenced by the rules of the games they play. If the budget of an agency and the salaries, fame, and prestige of its employees are directly related to the number of cases it brings, or wins, the result is unambiguously predicted by economic theory. They will bring large numbers of cheap and easy cases, emphasizing per se sections and those whose rules of thumb are satisfied with minimum toil. In some instances, a good deal of the toil can even be provided by special interests. Since there is no direct bonus or other mechanism permitting agency employees to share in any economic benefits they provide to consumers by avoiding or breaking important monopolies, they are not to be blamed if they emphasize different things than the broader social interest. The principal amelioration, if any, would arise either from irrational zeal or the possibility of later em-

\footnotetext{
${ }^{12}$ Observers have long noted impressive evidence of blind theologies in antitrust. Here is some more, if more is needed: confronted by even slender demands for data showing the importance of any or all monopoly power, some economists, at least, instantaneously complain that the data are unobtainable or that search for them would slacken the pace of antitrust; yet the same economists who plead lack of information see no inconsistency in their perennial assertions that the monopoly problem in toto is great and that this or that monopoly should be dissolved forthwith.

${ }^{13} 38$ Stat. 730 (1914), as amended, I5 U.S.C. $\$ \$ 12-27(1964)$.

14 For a plausible explanation of the historic pattern of Robinson-Patman Act enforcement by section, see Corwin D. Edwards, The Price Discrimination Law, esp. 69-72 (1959).
} 
ployment outside government in jobs requiring skills revealed in nontrivial litigation and research.

Lamentation about the "disproportionate" emphasis upon trivial research by college faculties is also somewhat misdirected. Students pay tuition to universities, not to individual teachers. If salary, promotions, and prestige depend upon producing large numbers of articles, that is what society will get, even if this means trivial articles and total inattention to teaching. The principal amelioration, if any, would arise from irrational zeal or the possibility of later and better employment in other universities or in nonacademic jobs requiring skills revealed in nontrivial research or good teaching.

I would welcome, and society should demand, a detailed statement showing how Federal Trade Commission priorities are actually established and pointing out what legal (and even political) constraints influence the process.

Presumably some operational priority standards could be developed by using industry (or market) size and, perhaps, bracket estimates of demand elasticity. For example, suppose we observe an industry in which price discrimination of one kind or another allegedly threatens competition. If the industry has been small under competition-as measured by value added, income generated, and so forth-it would be even smaller under monopoly. Unless there are good reasons to think that the industry price elasticity is extraordinarily low over wide ranges-betraying poor total substitution from all other industries-it simply does not very much matter what happens to competition in that industry. Of course, if there are no other kinds of industries in which bad things may happen and this kind is very numerous, aggregate effects could be serious. But so long as there are more important problems, economic analysis seems to suggest that they be looked into first, leaving fallen sparrows to heaven.

Of those who will agree with the truth of the preceding argument, some cynicsor realists, if there is a difference-will no doubt pronounce it naïve. For they have long pointed out that statutes like Robinson-Patman have little or nothing to do with economics and were not intended to. Some argue that such law is crassly political. Others will say that it cultivates among the masses a warm sense that no one is too trivial to be protected by his government and will contend that, to the benefit of all, this prevents far-reaching and dangerous radicalism.

I am aware that improved priorities could leave us worse off if the legal rules applied are anti-economic: it is better to bungle trivial things than those that matter. As a consequence, I will later have to comment upon the sense of the rules.

\section{II}

\section{Science and Pedagogy}

This brings me to a point over which-like most teachers-I am liable to make too much. It is the scientific and educative contribution of antitrust in general 
and Robinson-Patman in particular. The narrow problem arises partly because the statute and opinions incorporate various economic terms but leave behind the analytic framework from which they were wrenched. In addition, the cases often do not clearly point out either what has actually happened or the special or multiple senses in which certain economic terms are being used. Such a procedure could conceivably produce good policy and justice, but it surely sets low scientific standards. A good deal of what economists think they know about real-world pricing practices and markets has been learned from congressional hearings and the law cases as reported. And a good deal of that turns out to be surprisingly theoretical and inferential.

Long ago Aaron Director suggested to me what seemed at the time a strange experiment: take five or six FTC or court decisions, and for each summarize only what is definitely known to have happened; omit inferred motive and hypotheses about prospective effect. He made his point, for I tried it. It is truly remarkable what and how little often remains. A refinement can be added to the game: rewrite the summaries of facts in several styles, ranging from the colorless recitation found in clinical studies to a more readable one that shimmers with words like dominance, power, exclusion, and so forth. Whatever they may have learned from it, lawyers have played formally similar games for years. But they are concerned with somewhat different matters and forms, and are differently concerned with them. Economists are concerned with prediction and the general allocative significance of market definition, structure, and performance.

From pedagogical and informational standpoints, many FTC and court decisions are a bust. At a bare minimum, the opinions should point out which of the possible statutory injuries has been established and where, in the record, specific evidence of it is to be found. Lawyers are a scholarly lot, and this is a minimum standard for scholarship. For example, it is now fashionable for Robinson-Patman commentators to distinguish between general or "broad" reductions in competition (as in a tendency to monopoly) and "narrow" injuries to competitors (as in simple diversion of trade from one seller to another). Yet quite often it is impossible to discover from findings or opinions which type of injury has been inferred.15

There are two closely related reasons to decry this state of affairs. The first has to do with information and propaganda; the second, which I will later examine in detail, with the substance of social policy itself. Even if Robinson-Patman did not make policy but were simply pure rhetoric, many people would be interested in understanding it. Intellectual curiosity is hard to satisfy as things stand. Further-

\footnotetext{
${ }^{15}$ I am personally familiar with three studies that, among other things, analyze large numbers of Robinson-Patman cases to discover which type of injury has actually been inferred: John S. McGec, The Robinson-Patman Act and Effective Competition (unpublished Ph.D. dissertation, Vanderbilt University, I952); Robert C. Brooks, Jr., The Meaning and Determination of "Injury to Competition" Under the Robinson-Patman Act (unpublished Ph.D. dissertation, University of Chicago, 1959); ConwuN D. EDwards, The Price Discrimination Law (I959). In various ways, each of these studies reveals the difficulty of finding what type of injury was inferred. See EDwards, op. cit. stupra, at 521, 541.
} 
more, everything the Commission and courts write is news and is published, often at public expense. Arms of government command respect. A nonnegligible amount of what citizens (even students) learn about competition and monopoly derives from such utterances. They should therefore be really intelligible and make sense. Note the different informational content of these two (altogether hypothetical) summary statements about the same (altogether hypothetical) facts:

I. The Tillen Company, the third largest U.S. manufacturer of golf balls, discriminated in price in the sale of such golf balls to competing resellers, where the effect of such discrimination may be substantially to lessen competition or tend to create a monopoly, or to injure, destroy, or prevent competition.

2. In August, I963, the Tillen Company, the third largest U.S. manufacturer of golf balls, sold nineteen dozen golf balls to Benny's Sporting Goods for $\$ 4$ per dozen and six dozen identical balls to Piltz's Sports Store for $\$ 4.5^{\circ}$ per dozen. Both stores are in New York City. At least 200 stores sell golf balls in New York City. Piltz testified that he lost at least two customers to Benny because of the lower resale price charged by the latter. (Piltz, pp. II7-I36.) There is no evidence that a monopoly of golf ball manufacturers or retailers has been created by respondent's discrimination, that concentration is increasing in either field, or that either development is likely. Nevertheless; the statute also provides narrower standards of injury. They are met in this case. Because of Tillen's discrimination, Piltz lost some business, and that is enough.

I am not asserting that most, or even much, Robinson-Patman law rests on such narrow grounds. I am suggesting that it is very difficult to find out which and how much of it has. This is in principle quite serious, for biases favor all statutes. Not since heads of state appointed favorite horses to high office could one expect to find laws the avowed object of which is to do evil or spread ruin. All law is, by definition, well-intentioned.

It is important that the FTC adopt for its own utterances the same rules with respect to false and misleading advertising that it would impose upon business concerns. It may be that recent and current FTC practice in this repect is better than it used to be; but there would still be merit in explicitly recognizing a permanent obligation.

It is hard to say whether harm has been caused by congressional phrasemakers who have called resale price maintenance "fair trade" and trade diversion "injury to competition." It is acceptable to call "up" "down"; but perhaps we should be told about it each time. It would cost the FTC and courts much less to spell out what they think they are doing than it costs for outsiders to go to the transcripts to find what they did, with what, and to spread the word. There are very few economists who have read as many as three whole antitrust records. Not everyone who votes 
has been to college; not everyone in college studies Robinson-Patman or, even, economics; and it takes a while to explain even to bright economics students what may be going on in spite of what the statute itself seems to say. If there is value in knowledge, it might be diffused more cheaply if the FTC and the courts became less ritualistic and more reportorial in their summaries. Then, at least, outside analysts would better be able to choose which transcripts need to be looked into first. Probably the most reliable index has historically been the occasional full dissent that is based on data or economic inference. Ex-Commissioner Lowell Mason, for example, merits high praise in this role.

The foregoing criticisms and suggestions might turn out to be fairly trivial, as, for example, if economically valid conclusions consistently emerged for the wrong reasons or from the use of irrelevant or anti-economic standards. I have read just enough antitrust transcripts to be leery of Commission and court opinions and of scholarly analyses that do not go deeply into the transcripts behind them.

But apart from how well the Commission discharges its roles as reporter and as maker and enforcer of law, it is subject to another serious criticism. The FTC has much greater powers to inquire and to discover than does any academic researcher. Yet, I believe an impartial appraisal would show, during the last twenty years, each of several academic economists has produced more, more objective, and more important research on industrial organization and monopoly than has emerged from the FTC altogether. For an expert agency one of whose functions was to be inquiry and revelation, that is truly a remarkable record.

\section{III}

\section{Some Selected Aspects of Costs}

It is often asserted that all alleged cost differences that are based on marginal or incremental $\operatorname{costs}^{18}$ are economically illegitimate, whatever their status at law. This general denial rests upon particular parables, all of which incorporate special assumptions. Among the most important suppositions are that all customers are sold precisely identical goods that are produced, stored, and marketed continuously in ways and quantities and at times that are in all respects identical. Two major possibilities are now apparent.

First, marginal cost may decline as output increases. Charging one purchaser less than others might then be defended because marginal cost is lower with his business than it would be without it. Such a cost justification is economically invalid, since it is the total output rate that lowers marginal cost. Under present rarified assumptions, one buyer contributes as much to total output, and thus to

\footnotetext{
${ }^{16}$ Marginal cost at a given output rate is, in essence, the change in total cost resulting from the smallest possible change in output. Incremental cost has been used in various senses. The meaning here adopted is the change in total cost resulting from a finite-and possibly large-change in output. The latter concept, at least, is often operational and has been used, for example, in the computation of sealed bids.
} 
lower marginal cost, as does any other. Much more complicated and important is the broader question: does the resulting discrimination-for by economic standards that is what it is-increase consumer welfare? An example will illustrate the problem. If an unreformable monopoly produces with marginal costs that decline rapidly with output, welfare may be increased by price discrimination even though the monopoly industry would be viable without it. For if discrimination increases output, the resultant reduction of marginal cost could lower prices to all customers below what they would otherwise have been. Some assertions made with respect to discriminatory pricing of medical services rest, implicitly, on this theoretic argument.

A second possibility is that marginal costs may remain constant or rise with increased output but be below average cost. Consider now an arrangement that gives a marginal cost price to one group of buyers and prices at or above average costs to the others. In defense, it is said that the "marginal buyer" adds little (i.e., "less than average") to total cost and that the marginal cost price is therefore appropriate. So far as costs go, the defense is economically invalid, for the same reasons given before. But, as before, a welfare problem presents itself, even though marginal cost rises or is constant with increased output. Given a single-firm monopoly, permitting price discrimination may make some output possible when, without price discrimination, none would be produced. This could occur if no nondiscriminatory price that consumers will pay would cover the relevant costs of providing the service. Discrimination may collect enough revenue to cover costs, in which case the industry would survive. Consumers of the service are better off with it than without it. Less clear, perhaps, is whether discrimination would improve the general welfare as well, since resources used by the monopoly may be more expensive to other industries if the monopoly is permitted to operate by discriminating in sales prices. Even so, it is difficult to argue that consumers paying the higher prices for the service are hurt because others obtain it for less. Indeed, the contrary is true.

To this point, I have given little analytic support for cost distinctions that are based on marginal costs. In important instances, however, such distinctions are economically valid. Among other reasons, they now arise because of differences in the timing of purchases. When there are substantial peaks and troughs in the timepattern of demand, cost distinctions should be made on a marginal cost basis if they are to be economically meaningful. It is wholly inappropriate to allocate to off-peak buyers any charges for fixed facilities required to meet the demands of peak buyers, no increase in which is necessary to serve the others. Many regulatory commissions, accountants, and even economists are unlikely even to see, let alone appreciate, the point; but it is correct. ${ }^{17}$ However equitable it may appear to allocate fixed costs to such off-peak buyers, it is both altogether arbitrary and probably

\footnotetext{
${ }^{17}$ See, e.g., William S. Vickrey, Microstatics, esp. 225-36, 242-44, 256-58, 388 (I964); Ralph K. Davidson, Price Discrimination in Selling Gas and Electricity (1955); Wellisz, Regulation of Natural Gas Pipeline Companies: An Economic Analysis, $7 \mathrm{I}$ J. PoL. EcoN. 30 (1963).
} 
hurtful in terms of resource allocation. Indeed, in the economic sense, prices that impute such fixed charges to off-peak purchasers are themselves discriminatory beyond redemption. ${ }^{18}$ It is one thing grudgingly to tolerate such discrimination on grounds that the price flexibility required to avoid it is too expensive or that the relevant cost data are too hard to extract. It is quite another thing to require price discrimination of this type by rejecting marginal cost approximations out of hand. That is apparently what we tend to do. Basic functions of prices, after all, are to ration existing goods amongst competing uses and buyers and to signal desired changes in capacity and future outputs.

If the price discrimination law is intolerant of sensible pricing rules, there are various possible ways out. First, an attempt can be made to emphasize that the law calls for "real" rather than "estimated" or "calculated" costs. Nothing could be less real than allocating costs of providing capacity used fully in one period and little in another. Second, it may be possible to convince commissions and courts that, so far as seller and buyers are concerned, the "same" goods bought at peak and off-peak periods are simply different goods, ${ }^{19}$ and, as such, may fall outside the price discrimination definition.

An even more subtle problem arises because of risk. It exists whether cost defenses rest on average or marginal cost concepts. It is a highly important commonplace that risk costs something. In many-perhaps all-production and marketing processes, less expensive ways of doing things will be adopted if odds are good that certain minimum sales will be enjoyed. Risks of low sales are a barrier to employing techniques and processes that could be efficient at higher rates of output. Put in another way, processes and techniques adopted, and therefore costs, will be influenced by expected output and sales. Even if, under certainty and other unrealistic conditions, real costs of service did not vary among customers, risk changes the picture. A much simplified example shows how. Suppose that for the relevant future a producer expects sales to be somewhere between 1,000 and 6,000 units, with his own probability "weights" attached as follows:

(x)

Sales, physical units
1,000
2,000
3,000
4,000
5,000
6,000

(2)

\begin{tabular}{cc} 
Probability & $(I) \times(2)$ \\
.20 & 200 \\
.20 & 400 \\
.20 & 600 \\
.30 & 1,200 \\
.05 & 250 \\
.05 & 300 \\
\hline .00 & 2,950
\end{tabular}

${ }^{18}$ This point is made most convincingly by DAvidson, op. cit. stupra note 17 .

${ }^{10}$ This is true even if off-peak buyers did not incur offsetting storage or other costs. This point is made to avoid confusion with the increasingly popular plea that no competitive injuries arise when buyers' additional costs offset their price-savings or that such favorable prices are analogous to functional discounts given to defray distributors' differential expenses. 
Although it is true that 4,000 units is the most likely single quantity, all things considered, the expected value of sales is $2,95^{\circ}$. What output our producer actually decides to tool up to produce, and how he does it, will of course also depend upon costs under different plans and the costliness of being wrong once any production plan is adopted. Tooling to produce, say, 4,00o units could be disastrously expensive if only 2,000 are sold. Similarly, apparatus planned for 2,000 units may be highly inefficient if 4,000 are actually sold.

What happens to sales prospects and costs if firm contracts could be made in advance for a total of, say, 2,00I units? The probability of selling 1,000 or 2,000 units is now zero. Assuming that the other sales possibilities (and their relative probability) are not changed by the contracts, ${ }^{20}$ two highly unfavorable possibilities have been eliminated, raising average prospects. One plausible result is the following:

(I)

Sales, physical units
3,000
4,000
5,000
6,000

(2)

\begin{tabular}{cc} 
Probability & $(1) \times(2)$ \\
$.333 \ldots$ & 1,000 \\
.500 & 2,000 \\
$.083 \ldots$ & 417 \\
$.083 \ldots$ & 500 \\
\hline I.000 & 3,917
\end{tabular}

The expected value of sales has now risen to 3,9r7 units, an increase of about onethird. It is entirely reasonable that the producer alter his production and sales apparatus as a consequence. It also seems likely, if not absolutely inevitable, that this will lower costs. Such cost reductions are directly attributable to a reduced risk of small volumes. In this simple example, those who contracted in advance permitted or "caused" the cost savings.

Note, now, a peculiar and important aspect of this whole affair. On entirely plausible assumptions, reduced risk permitted cheaper ways of doing things for all customers. A post-hoc cost analysis, even if it could be made perfectly by exemplary accountants, might reveal that (marginal or average) costs of serving all customers are absolutely identical. ${ }^{21}$ Presumably no cost defense would lie. It would be fruitless for the producer to argue that those who contracted made costs for everyone lower than they otherwise would have been. And this is a serious flaw. For it is naîve to suppose that those buyers who contract, thereby increasing their risks, will do so for nothing. If there is nothing in it for them, because law does not permit them to get discounts, they will stop contracting. Costs then would be higher for everybody, a development that all but the perverse should lament.

\footnotetext{
${ }^{20}$ Strengthened demand might underlie the increased willingness to contract. This would presumably alter the producer's prospects and probability weights.

${ }^{82} \mathrm{As}$, for example, when the quantities bought, the timing of purchases, and so forth, turn out to be identical for all. This need not be the case; and, indeed, other cost aspects of the transactions could be either reinforcing or opposed.
} 
An additional point needs development. When a firm's customers are numerous (and each relatively small), it might appear that it would not pay to discount for advance contracts. The conclusion is based on the fact that no such single contract would be worth much. The conclusion is incorrect. For experience will reveal, if vision does not, that each given discount for contracts will induce so many customers to contract and that this number will rise with the discount offered. Of course, a seller will want to discount as little as possible for a given volume of contracts, but competition would force him to discount up to the full cost savings that the contracts permit. Relax assumptions somewhat, so that buyers do not all take the same quantities per unit of time. In some ways matters are now more complicated: there are two possible sources of cost savings rather than only onc. First, volume discounts or firm contracts may reduce risks, making it possible to adopt generally cheaper ways of doing things; and, second, once more efficient processes are adopted, it may be less expensive to fill larger orders, and so on. In principle, at least, the law permits prices to reflect the latter type of savings but apparently makes no room for the former.

Even if the law were sympathetic, which evidently it is not, it would be difficult to cost-justify such schemes. Doubtless some will argue that rules sufficiently relaxed to permit cost-justification in cases like this would permit anything. The law would then become difficult to enforce. There are several answers. First, it is altogether clear that the quality of law is not to be judged solely by how easy it makes life for those who administer it. Second, recognition of new types of socially-if not legally-justifable cost-savings demands more meaningful standards of adverse competitive effects. It makes it even harder, in classrooms if not in court and hearing rooms, to argue that overly sensitive indexes of competition don't matter so much because a cost-defense escape is provided. Re-emphasis on competition standards, even if forced, could be wholesome.

\section{IV}

\section{Volume Discounts}

The FTC has often concluded that volume discounts may injure or lessen competition. ${ }^{22}$ Such a finding could rest upon the different prices accorded competing purchasers who buy different volumes or upon the effect of volume discounts in barring entry or "access" to the primary line in which the seller is engaged. I will ignore the problem of "injury" in the secondary line, since no unique problem arises with respect to it.

Long ago the Commission specifically emphasized that volume discounts inhibit

\footnotetext{
${ }^{22}$ In pure form, volume discounts apply to quantities purchased over a substantial interval of time rather than to quantitics bought at or delivered at one time. Volume and quantity discounts are sometimes joined.
} 
new entry and expansion by relatively smaller firms. ${ }^{23}$ More recently, Robert $\mathrm{C}$. Brooks, Jr., in strengthening the logical core of the old FTC argument, has sharply narrowed the area of its potential application. ${ }^{24}$ We are in his debt.

The bold FTC-style argument can be analyzed first by stripping it down to a simple form. Assume that a (relatively) large firm sells one product at net prices that decline as a buyer purchases larger volumes. Any buyer whose purchases are at or near the minimum volume necessary to qualify for all but the lowest discount bracket is allegedly insulated from blandishments of other sellers. This is said to be so because transferring some, but not all, of his business will require that the price on units bought from the new supplier be low enough to compensate the buyer for the higher discount lost on all the other business. ${ }^{25}$ Of course, as Brooks recognizes, this clog on access will be absent or mitigated if a buyer's volume is substantially above a volume discount breaking point, if the volume brackets are simply not enforced, or if, no matter where a buyer is located in the volume scale, there are enough or large enough outside suppliers to satisfy his total requirements.

As I interpret his article, Brooks still claims too much. Examine the one-product case. $^{20}$ In the first place, before economists should have any interest in the question, there should be some evidence that prices substantially exceed marginal cost-i.e., that there is a monopoly problem. Second, as will become abundantly clear later on, we should be reasonably sure that the monopoly does not rest on size economies before attributing monopoly or no entry to volume discounts. Third, even if there is such a problem, economic appraisal of it presumably requires knowing whether the discounts are broadly based on cost savings. ${ }^{27}$

A new firm would face no unique "access" problem if the optimum size of seller is equal to or smaller than the sum of the following: (I) volumes of business done in the lowest discount bracket; (2) all business in excess of the lower volume limit in those brackets in which buyers now find themselves, and (3) other business that will result in lower discounts but that still yields prices equal to or greater than marginal cost. ${ }^{28}$ Even this may be too restrictive. For, if newcomers can offer equivalent goods, ${ }^{29}$ it is enough for access by existing sellers that in sum they are or

\footnotetext{
${ }^{33}$ Sec, e.g., American Optical Co., 28 F.T.C. I69, 18I-82 (1939); Simmons Co., 29 F.T.C. 727, 740-42 (I939).

${ }_{24}$ Brooks, Volume Discounts as Barriers to Entry and Access, 69 J. PoL. Econ. 63 (I96I).

${ }^{25}$ This alleged compound leverage would be greater the smaller the volume of business transferred to the newcomer, assuming a buyer's volume is reduced below a discount-bracket breaking point. All, or any part, of the business of any buyer whose volume of purchases qualifies him only for the smallest discou-t is in any sense quite "accessible" to competing sellers.

${ }^{20} \mathrm{He}$ often commingles diversified and one-product lines, absolute and relative size, and patent and de facto monopoly.

${ }^{27}$ I do not mean that a cost defense must satisfy any given FTC accountant to be meaningful economically. See the discussion of costs supra.

${ }^{28}$ This is apparently sufficient for the entry of at least one firm, but not necessary, for the volume of purchases now made will be increased at lower prices. I say "apparently" sufficient because it may turn out that the optimum size of firm is so large relative to the total market that there is not room for two firms. That is natural monopoly.

${ }^{20}$ If they cannot, it is at least premature to say that volume discounts are the real barrier.
} 
can become big enough to satisfy all of the requirements of one or more even of those sellers whose volumes are close to a volume discount breaking point of the "dominant firm." 30

Of course, competition is more important than "access" to business by specific firms. It may be that every existing firm has "access" to business (in the sense outlined above) and is prosperous but that when all this "accessible" business has been acquired there are still not enough firms to produce a roughly competitive outcome. What, then, about entry? Suppose, for example, that several buyers who together make a large percentage of the total purchases are attached to the dominant firm and that the volume of each (identical or not) is just above a volume discount breakingpoint. What would prevent the entry of new firms? If the volume of each of these large buyers is smaller than or equal to the optimum size of selling firm, volume discounts are not a barrier to entry. It is conceivable, I suppose, that any such buyer's volume is still so large relative to the total market-i.e., that total demand for the product becomes highly inelastic below present prices-that there is no room for one more optimum-size firm-i.e., that there is natural monopoly (or natural oligopoly, if you prefer) ${ }^{31}$ But this fact appears to have nothing to do with volume discounts, since it would operate without them.

What if the volume of each of the relatively large buyers is larger than the minimum optimum size of seller? Several firms could enter. ${ }^{32}$ It may be argued that no single seller will enter until he is sure that there will be enough newcomers to furnish the total requirements of at least one of the larger buyers. Perhaps, then, none will enter. Apart from the implicit assumption that information is frightfully poor and expensive, this argument suffers another defect. Any such larger buyer will have a real incentive to encourage entry of enough firms to break his present attachment. ${ }^{33}$ One can certainly imagine his offering firm contracts, or at least prices, to potential entrants, integrating vertically, or informing the business community (probably the world) of his present plight.

Though volume discounts now look somewhat tattered as an entry and "access" barrier raised by a single-product firm, ${ }^{34}$ there remains the issue of the "dominant"

\footnotetext{
${ }^{80}$ Some may argue that if they are not already big enough they cannot grow enough. This scems somewhat strange. For if monopoly rates of return are available they will have the best incentive to grow. Critics should point out precisely what would keep them from growing and what evidence of it exists. Vague complaints about "capital requirements" are certainly not sufficient.

${ }^{32} \mathrm{~A}$ subtle and misleading geometric game could be commenced at this point. It might be argued that the available business of one of these relatively large buyers is too small for optimum operation, but the business of two is so large as to produce diseconomies of large size to the cntrant. How, then, do we explain why the "dominant" firm is even larger (and that some other sellers may be so much smaller)?

${ }^{32}$ This could be expected if there is a unique optimum size. But, again, why is the "dominant" seller so much larger?

${ }^{83}$ This assumes he is paying higher than competitive prices. If not, there is no rationale for entry into this segment of the market-or any other, since larger buyers get lowest prices. In any case, the other segments-composed of smaller buyers-would pose no such problem.

${ }^{84}$ It is not really a question of the total number of different products sold but of the number lumped into one volume discount scale.
} 
seller with a diversified line, all items of which are included in a single volume discount plan. Though Brooks does not ask them, two additional questions should be answered: ${ }^{35}$ (I) Are these different products produced or sold together because doing so reduces costs? ${ }^{36}$ (2) Are they substitutes or complements or are they unrelated in demand? ? $^{37}$

Now the objection to this type of volume discount has been that "it automatically makes any part of ... [the seller's] line that a potential competitor might consider entering the lowest profit part."38 As a consequence, so the theory goes, he enters none. If it turns out that there are not effective patent or other artificial impediments to entry into any of the dominant firm's diversified product line, we can largely apply the economics previously developed for the single-product case. An exception apparently arises if present or potential competitors are incompetent to make one or more products in the line but are quite capable, if given a chance, of effectively producing the others. If there are economies of producing or selling all together, the dominant firm would then have an advantage that most would characterize as "natural." Mechanically, the results appear to be closely similar to the situation where one of the products is patented, and I will discuss them together.

The question then becomes whether volume discounts can be used to extend the monopoly of one product to products that otherwise would be produced competitively. Note that there is little reason to brood about monopoly in the first product, for it is largely irremediable. Assume that there are no economies of joint production or sale and that the products in the line are unrelated through price. ${ }^{39}$ Only a part of the business available in the one-product case is "accessible," since we assume one product is irremediably monopolized. That leaves such business in the other products that is done in the lowest discount brackets plus whatever volumes will not place buyers in lower discount brackets plus that which would place buyers in lower discount brackets but which can be attracted at prices equal to or greater than marginal cost. ${ }^{40}$ As before, if this volume is greater than or equal to the optimum size of selling firm, there is room for one or more firms. There may even be room for enough firms to establish competitive prices for all but the irremediably monopolized good.

But there may not be room for enough firms; and here Brooks may have a point.

\footnotetext{
${ }^{35}$ Others previously asked remain relevant: ( $r$ ) Is there a significant monopoly problem? (2) May it rest on economies of size? (3) Are the volume discounts plausibly related to obvious cost savings?

${ }^{30}$ Such goods are called complements in production or sale.

${ }^{37}$ Cutting the price of one substitute reduces the demand for the others. Cutting the price of one complement increases demand for the others. See Bowman, Tying Arrangements and the Leverage Problem, 67 YALE L.J. I9 (1957).

${ }^{38}$ Brooks, supra note 24 , at 69 .

${ }^{30}$ That is, a change in the price of one product does not change the demand for the others. I doubt that this case is very much encountered in the real world, since it is not clear why some or all buyers would then purchase the products together.

${ }^{10}$ Whether Brooks' arithmetic examples are atypically severe, the direction of their effects is correct. What he does not explicitly recognize is that having to recompense customers for lost discounts may still leave the challenging seller(s) with higher than competitive prices.
} 
For some, perhaps small, part of the potentially competitive goods market a shelter might have been erected. I have, of course, strengthened Brooks' case by assuming an iron-clad and important monopoly on one good. ${ }^{41}$ Yet, in such a case, it remains a fair and troublesome question why the monopolist simply does not extract all of the monopoly profit by charging higher prices explicitly for the primary monopoly good itself.42 For that is where its power really inheres, and no one would cherish another illusion.

In any case, it appears that the old FTC theory with respect to volume discounts must be narrowed substantially even according to Brooks and still more according to my argument. If Brooks is correct, two types of situation that bear watching are those in which (I) the largest buyers are too large to be served by one seller of minimum optimum size and/or (2) there is a diversified line. In my view, the real problem-if any-is more likely to arise when ( 1 ) the minimum optimum size of seller is large relative to the market and/or (2) there is strong monopoly in some part of a diversified line.

To be cautious, then, the FTC could investigate volume discounts used in these rather narrow fact situations. Proceeding much more broadly against them is probably to tilt at windmills, which is not necessarily innocuous since windmills produce flour if left alone.

\section{V}

\section{Predatory Practices}

Monopolizing techniques tend to increase the spread between marginal cost and price. Cartels and horizontal mergers are classic forms, the theory and practice with respect to which are reasonably well settled. Arson, mayhem, and assassination are also plausible candidates in principle, since they tend to be both more expensive to victim than to predator and less expensive to predator than the benefits they make it possible for him to reap. Deferred rebates ${ }^{43}$ and, possibly, volume discounts may also be practicable exclusionary techniques under some conditions.

Much less plausible, in my opinion-if, indeed, plausible at all-are general ${ }^{14}$

\footnotetext{
"1 This means more than, say, that one good is merely patented. It implies that the restraint bestows important monopoly power over a wide range of prices, i.e., demand clasticitics substantially less than infinite.

${ }^{12} \mathrm{We}$ should include the possibility of all-or-none perfect discrimination that charges, for given volumes, almost as much as would induce the buyer to do without the good altogether. Compare Director \& Levi, supra note 4, at 290-9I, with Bowman, supra note 37.

\$s For an analytic history of collusive loyalty ties in ocean transport, sce McGec, Occan Frright Rate Conferences and the American Merchant Marine, 27 U. Ch1. L. Rev. 191, csp. 21 3-38 (196n), and A. R. Ferguson, E. M. Lerner, J. S. McGee, W. Y. Oi, L. A. Rapping \& S. P. Sibotica. The Economic Value of the United States Merchant Marine, esp. 376-404 (z961).

"Modigliani, New Developments on the Oligonoly Front, $66 \mathrm{~J}$. PoL. Ecov. 215, 217 (1058), and sources cited therein. A key, and doubtful, assumption is "that potential entrants behave as though they expected existing firms to adopt the policy most unfavorable to them, namely, the policy of main-
} 
or discriminatory price cuts to drive out present, or keep out potential, rivals. I have explained elsewhere why I doubt that discriminatory price cutting is a very sensible monopolizing technique. ${ }^{45}$ Furthermore, theoretically sensible or not, there have been surprisingly few cases (even as reported) that so much as look at first glance to be predatory price discrimination. Nevertheless, many people are still concerned about predatory price discrimination, and I admit that the questions of theory and fact that it poses are less frivolous than cold-trailing bubble gum and baseball tradingcard "monopolies."

Even those who fear predatory price discrimination should be careful in framing legal rules to avoid it. First, it should now be clear that at worst there have not been very many instances of attempted, let alone successful, predatory pricing, even in periods and places with no antitrust laws. This suggests that necessary conditions for successful predation are not ubiquitous, and that narrow rules can be developed. Second, ordinary spatial competition may often look like what is called "predatory" pricing. Enforcing sweeping rules against these common symptoms could be like feeding a fine bird dog powerful poisons to avoid a kind of parasite that is rare, if it exists at all.

Most would probably agree that predatory price cutting is unappealing, if not ludicrous, when the minimum efficient size of firm is small relative to the market and the skills necessary to enter are not rare. This, $I$ should think, rules out most if not all trade and agriculture. Predatory price cutting would require large relative size-i.e., monopoly power-which raises the possibility of proceeding against the monopoly directly. It also rules out firms with minority market shares, I should think. Indeed, even a firm with high regional but low national share is not a very good candidate, since other national firms are a menace to advancing prices (and profit) afterwards. A firm which has a very high national market share but which faces numbers of rivals in most or all regions is not a prime candidate for predator either. Not only is this situation symptomatic of potential entry everywhere, but it would be more than slightly expensive to kill off present rivals. Long-lived and large capital investment is not too favorable, since prices below average total costs (but above average variable cost) would take a long time to kill. Holding prices below average variable costs would be frightfully expensive. Furthermore, even if predatory pricing were undertaken and worked, rivals' plants would probably have

taining output while reducing the price...." Even on purely theoretic grounds, the assumption seems strange. For any entrant knows that, once he is actually there, the "dominant" firms can probably do better by adjusting to his existence. In any case, the theory suffers when it is tested by the history of early American "trusts" and more recent experience. For example, see George J. STIGLER, Five Lectures on Economic Problems 46-65, esp. 63-65 (1949), and Osborne, The Role of Entry in Oligopoly Theory, $72 \mathrm{~J}$. Poz. EcoN. 396 (1964).

15 McGee, Predatory Price Cutting: The Standard Oil (N.J.) Case, I J. Law \& Econ. I37 (1958).

${ }_{10}$ This particular trail has just been abandoned: Topps Chewing Gum, Inc., 3 Trade Reg. Rep. I 17251 (FTC I965). 
to be bought. ${ }^{47}$ Enforcing laws against monopolizing by merger would make the whole procedure still more unattractive.

For those who want to exercise against "predatory" price cutters, where are they least unlikely to be found? Look for a prosperous and liquid firm with high national share of the sales of a distinct product, with no rivals most places and with very few elsewhere. Rivals should be operating in absolutely small markets. There should be powerful impediments to entry-as, for example, when very scarce and specialized talents are necessary to engage in the business and all of them are now engaged in it. Rivals should be poor, illiquid, and-for some reason-incapable of borrowing. Average variable cost should be close to price before price cutting begins. These conditions do not explain why the dominant firm would engage in more expensive predatory activities rather than merging or colluding with its rivals, but they do afford some chance for cutthroat activities to work mechanically. ${ }^{48}$

One of the troubles with the "predation" complex is that it focuses policy against "predator" and in favor of "prey," rather than toward competitive allocation goals. In one sense, competition is a process thought to be more probable within some industrial structures than others. In another sense, it is a set of allocative performance standards. But in no useful sense is competition a cast of characters. If one or many farmers fail or die of plague, competition is not reduced. If one pure monopolist totally displaces another, competition is not reduced. If one of only two sellers buys or assassinates the other, competition is reduced, at least for a time. If a large proportion-just how large a share is necessary no one can say in advance for all cases-of the capacity of the industry is merged into one dominant firm, competition is reduced. Similarly for effective collusion. In principle, the issue is whether there is a widened gap between price and marginal cost.

Assume that a monopolist sells in two or more markets and that significant entry occurs for the moment in only one of them. Traditional nonpredatory theory predicts that price will fall in one market but, depending on the slope of marginal cost. perhaps not in the other. Entrants would prefer, of course, that the monopolist never be permitted to cut prices anywhere, but that would serve consumers poorly by deferring convergence of price and marginal cost. ${ }^{40}$ So long as the same prices that cover the monopolist's variable costs would not cover an entrant's total costs, entry will not occur. Rules that force the monopolist to retire from that market, ${ }^{50}$ or that otherwise raise prices in it, are questionable on allocative grounds. No doubt discriminatory price cutting has been used by new firms on entering an industry and by established firms in markets into which they are entering for the first

\footnotetext{
${ }^{17}$ Otherwise, they would be reopened by the old staff or picked up very cheaply by adventurers and operated when prices rose.

${ }^{8}$ They also mean that the maximum increase in monopoly power to be gained is relatively small.

49 The danger of rules whose function is simply to increase the number and comfort of sellers can well be seen in the theory and practice of resale price maintenance. Probable effects of legally en. forced, and high, retail margins are decreased "concentration" in retailing-and high prices.

${ }^{50}$ Possible examples are ouster and prohibitions against freight absorption and other discrimination.
} 
time. At least the immediate effect of such price cutting is to press prices towards marginal cost. Perhaps we should be reasonably sure, then, that greater movements in the other direction are likely to follow before intervening.

Hopefully without encouraging further congestion in the courts and subsidy to the accounting profession, perhaps the bar and economists should consider the following possibility. Marginal cost is often difficult to estimate. Average variable cost and "direct" or "prime" cost are much easier to ascertain from existing records. If there were solid grounds to suspect predatory pricing, perhaps it would be feasible to discover whether prices are being held below the suspected predator's average variable cost for periods "unreasonably" long to be purely promotional. Such investigations could open the door further to the difficulties and frustrations now encountered with section 2 (a) cost defenses. ${ }^{51}$ On the other hand, the notion may be broadly appealing and may not be worse than either excursions into "intent" and other shadow lands or overly broad rules that tax all geographic price differences.

Yet, when all is said and done, the present Clayton Act law of horizontal mergers and the Sherman $\mathrm{Law}^{52}$ are more than sufficiently powerful to attack the whole problem, if there is one. ${ }^{53}$

\section{VI}

\section{SeCONDARY ANd NTH-LeVEe "INJURY"}

Though there is not space here fully to analyse the problem of injury to or lessening of competition at secondary and lower levels, I would apply most of the foregoing argument to it with slight change. Indeed, consumer hurt through damage to competition is probably less likely on secondary and lower levels than at the primary level. Numbers of firms are often higher, scale economies generally not massive, and entry is often quick and easy. It is useful, however, to pose a few additional questions that must be answered in each case if Robinson-Patman is ever to be as successful a policy in the economic sense as it has apparently been in the political sense.

Imagine a single-firm manufacturing monopoly whose many identical customers compete in reselling to identical final consumers. Note that the allocative effect of monopoly at the manufacturing level is transmitted to the consumer level, even when competition amongst resellers is perfect. ${ }^{54}$ Apart from entry into manufacturing-

${ }^{61}$ For a monumental study of those problems, see Herbert F. TAGGart, Cost Justification (1959). As one who has read a mere thousand pages of cost defense testimony, I can only marvel at Taggart's tenacity.

26 Stat. 209 (1890), as amended, ${ }_{5}$ U.S.C. $\$ \S x-7$ (1964).

${ }^{63}$ As Bork \& Bowman put it, "Has anybody ever seen a firm gain a monopoly or anything like one through ... price discrimination?" Bork \& Bowman, supra note 6, at 367 . See also Bowman, supra note 6 , at 421 .

to That is, if from the beginning the manufacturing monopoly had integrated completely from mill through retail shop at the same marketing costs as would have prevailed for independent resellers, output at manufacturing and retail levels would be the same as when there is explicit monopoly only in manufacturing. This does not argue that consumers would be unaffected if a strong cartel of independent 
which involves the problems of "primary" competition discussed above-what changes in assumptions could produce price discrimination and "injury" at the secondary level? They are basically of two sorts. ${ }^{65}$ First, for various reasons costs might differ systematically amongst resellers. Naturally the manufacturer would prefer to deal only with efficient intermediaries, but the output he wants may require using outlets amongst which costs vary widely. If he is able to discriminate and consumers are all alike, he would charge higher prices to low-cost resellers and lower prices to high-cost ones. Ideally, all resellers would charge the same prices to consumers, and all would earn only competitive returns. In general, consumers would not be hurt, apart from the usual monopoly effects, and could easily be benefited by such discrimination. If nondiscrimination had been succeeded by discrimination, the sales of one group of resellers would have been reduced and those of the other increased. This "trade diversion" has nothing to do with lessening of competition. There is a monopoly problem, but secondary-line injuries have little or nothing to do with it.

Second, resellers might all be alike, but consumers could have different demands for the product. If the consumer markets are separable, the monopoly may obtain the desired prices at the consumer level by discrimination amongst resellers. Much the same conclusions about "injury" apply in this case as before. The plight of the ultimate consumer is less clear. Output effects of discrimination would have to be evaluated with others: consumers as a whole would pay more for each total quantity sold.

In cases of dominant-firm monopoly, oligopoly, and imperfect competition, matters are somewhat more complex. Apart from price differences that reflect cost savings of all kinds, there will normally be a certain amount of real price discrimination amongst resellers. Some of it, at least, will result from rivalrous seller behavior; and stopping that may remove such price competition as can normally be expected.

As before, the "injury" focus should not be on participants but upon estimated changes in the price-marginal cost relationships that consumers face. Injury at primary levels has already been discussed. A few additional remarks about secondary-line effects are probably necessary. In evaluating discrimination, several logical presumptions should be kept in view: No seller will cavalierly scuttle the resellers he depends upon for survival, create monopsony power in resellers with whom he deals, or undertake to increase reseller margins unnecessarily. Add to this a question: Would disadvantaged resellers or consumers be better off if the primary

resellers were created to confront the manufacturing monopoly. Consumers could hardly be helped by this development, called "bilateral monopoly," and could be hurt. See George J. Stigren, THE Theory of Price 240-4I (1952).

E5 Both require wholly or partly separable markets. If market overlaps are complete, there is but one market, and higher prices in one part would drive all custom to the others. This requires, for the first example, no resale amongst resellers; in the second, no resale amongst consumers as well. 
seller refused to deal with some resellers instead of discriminating against them? So far as I can see, there are two not wholly impossible sets of circumstances that bear open-minded investigation, though theory and fact with respect to both are in a most untidy condition. Both would apparently require certain critical relationships between market size and most efficient size of firm-of the sorts previously alluded to in connection with volume discounts-and perhaps institutional entry barriers as well. The first is bilateral monopoly, with very high single firm shares on both sides of the market, and the possibility of quid pro quos that might conceivably-given critical assumptions about entry, economies of size, and market sizeinfluence primary-line and secondary-line competition together. ${ }^{56}$ The second, and closely related, case might conceivably occur if an almost pure monopsonist is also an almost pure monopolist. Both of these situations require so many and such restrictive assumptions as surely to be quite rare, at worst, but are sufficiently interesting to merit further theoretic and empirical investigation. In addition, both require such a degree of actual monopoly power as more properly to fall within the province of the Sherman Law than within Robinson-Patman concepts.

\section{Conclusions}

Using standards of allocative efficiency, with consumer benefit the goal, I have argued that the Robinson-Patman Act has suffered both from inadequate economic theory and explicit anti-economic biases; has been enforced with no socially rational system of priority; and has produced a core of scientific information that is relatively meager and sometimes wrong and implicit definitions of competition and efficiency that are confusing to the body politic. Competition is not handicap trapshooting, and I do not think it pays to force the better performers to stand farther from the targets.

But, unlike some critics of the law, I am also concerned over the achievable and desirable limits in reforming a congenitally flawed statute by shifts in Commission and court sentiment. This kind of concern is a continuing one in our society, and can be summed up in the words of Edward H. Levi:

In many controversial situations, legislative revision cannot be expected. It often appears that the only hope lies with the courts. Yet the democratic process seems to require that controversial changes should be made by the legislative body. This is not only because there is a mechanism for holding legislators responsible. It is also because courts are normally timid. ... The difficulties which administrative agencies have in the face of sustained pressure serve as a warning. When courts enter the area of great controversy, they require unusual protection. They must be ready to appeal to the constitution. ${ }^{57}$

\footnotetext{
${ }^{58}$ See the rather puzzling case of the "BAPS" ring and the general discussion of abstract possibilities in McGee, Ocean Freight Rate Conferences and the American Merchant Marine, 27 U. CH1. L. REv. 191, 238-42, 269-70 (1960).

it Edward H. LeVi, AN Introduction to Legal Reasoning 23 (1959).
} 